\title{
Small sinkhole-like features in alluvial plains: the example of Paganico (Lucca Plain, Italy)
}

\author{
M. Dell'Aringa ${ }^{1}$, R. Giannecchini ${ }^{2}$, and A. Puccinelli ${ }^{2}$ \\ ${ }^{1}$ Geologist, external collaborator, Lucca, Italy \\ ${ }^{2}$ Earth Sciences Department - University of Pisa, Pisa, Italy \\ Correspondence to: R. Giannecchini (rgiannecchini@dst.unipi.it) \\ Received: 6 June 2013 - Published in Nat. Hazards Earth Syst. Sci. Discuss.: 17 July 2013 \\ Revised: 27 November 2013 - Accepted: 29 November 2013 - Published: 6 January 2014
}

\begin{abstract}
Paganico is a little village located in the southeastern portion of the Lucca Plain (northwestern Tuscany, Italy). Since the seventies, a few square kilometers' area around Paganico has been involved in the opening of small cavities (sinkhole-like) on the land surface. At the beginning they were very small and sporadic. Later on the phenomena were characterized by a significant extension, increasing in frequency and size (up to $2 \mathrm{~m}$ in diameter and depth), causing inconvenience to local people, agricultural operations and occasionally a little damage (cracks to buildings, fencing walls and outside floorings).

The cavities prevalently occur at the end of the dry season, during or immediately after the first intense rainy events, that is, between the end of summer and early autumn. Even so, the predisposition and triggering causes at present are not completely clarified. Therefore this study is aimed at individuating the triggering and evolution mechanism of the Paganico sinkhole-like features, particularly referring to the stratigraphic, hydrogeological and geotechnical features of the involved materials.

Another important issue made clear with this research is represented by the overexploitation of the local aquifer, characterized by particular hydro-structural conditions. In fact, the Paganico underground shows three horizons with different lithologic, hydrogeological and geotechnical properties: a superficial silty-sandy horizon (2-3 m thick), which is particularly involved in collapses; an intermediate siltyclayey horizon (2-4 m thick); and a lower and thick gravelpebbly horizon, characterized by important water resources and heavy pumping. Since the seventies, such water pumping rose considerably due to the local demographic (well field), industrial (paper manufacture) and agricultural development.
\end{abstract}

From a hydrogeological point of view, this area is consequently characterized by two water tables: a temporary one, housed in the superficial silty-sandy horizon (perched aquifer), and a second one, confined, associated with the lower gravel-pebbly horizon (aquifer). The perched aquifer and confined aquifer are separated by an impermeable siltyclayey horizon. According to the observations resulting from this study, the latter probably tends to fracture by desiccation during the dry season, originating water exchange between the two water tables during the first important autumnal rainfall, depending on the pumping conditions, which lower the piezometric surface of the confined aquifer. Cracking would also characterize the superficial horizon. Thus, the water exchange would produce erosional phenomena in the superficial material, with removal of the fine fraction and collapse. This process could be at the origin of the cavities opening.

\section{Introduction}

Sinkholes are common in many countries and in different geological and morphological environments, involving both bedrock and cover materials (Waltham and Fookes, 2003; Waltham et al., 2005; Parise and Florea, 2008; Galve et al., 2009; Del Prete et al., 2010). Bates and Jackson's (1987) glossary defines sinkhole as a circular depression in karst areas, a definition similarly proposed by Waltham et al. (2005). The latter authors, however, highlight a certain confusion in using this term, by not always associating sinkholes to karst areas. On the other hand, they emphasize how the term sinkhole is very descriptive, and this may justify a larger use. 
The Paganico cavities do not belong to karst environments. They are very small (generally $60-70 \mathrm{~cm}$ in diameter and depth) and open in an alluvial plain in which the bedrock is very deep (more than $350 \mathrm{~m}$ ) and not necessarily carbonatic (Ghelardoni et al., 1968). Similar phenomena were observed also by Marr (1955), Warn (1966), Garcìa-Ruiz et al. (1986), Higgins and Schoner (1997), Sbrilli (2004) and Davidson (2012).

For the reasons just discussed, the term sinkhole-like feature seems more proper and will be used in this paper.

Since the seventies the area around Paganico, a little village in the southeastern part of the Lucca Plain (Tuscany, Fig. 1), has been involved in the formation of soil collapses and small holes. At the beginning, the phenomena were isolated and characterized by diameter and depth of only few decimeters. Inhabitants were not troubled because the zone was mainly rural, and ploughing often hid them. Since the seventies and especially the following decade, the phenomena intensity has increased: the sinkhole-like features have opened more frequently, while in some cases the dimension have reached $2 \mathrm{~m}$ in diameter and depth. According to local people, they also caused problems with agricultural machinery and operators and little damage to small and old buildings, outside walls and floorings. The opening of the cavities seems mainly to occur at the end of the dry season (September-October), during the first intense rainfall events.

The Paganico area is particularly rich in groundwater (Nardi et al., 1987). Since the remote past, the apparently inexhaustible aquifer housed in gravel and pebbles has been exposed to considerable withdrawal and several water well fields were established starting from the 1960s (Fig. 1). Moreover, in this area there are also many domestic and agricultural wells. In time, the water pumping considerably increased, owing to the demographic development of the area and agricultural needs, but also in relation to the birth of one of the most important Italian and European paper industry poles. It is well known that paper production needs large amounts of water (approximately $100-200 \mathrm{~m}^{3}$ per ton).

The considerable water demand in this section of the Lucca Plain induced a strong drawdown, with progressive aquifer impoverishment, subsidence (Canuti et al., 2005), drying up of many Roman-type superficial wells, loss of several resurgences which characterized the area in the past (Nardi et al., 1987), and the formation of small sinkhole-like features around Paganico.

This study is a contribution to understanding the causes of the sinkhole-like features. Many surveys were carried out in order to provide convincing explanations concerning the triggering causes and developing mechanism: collection of existing data (e.g. location of past cavities, stratigraphic and hydrogeological data), on-site survey (individuation of new cavities, acquisition of new stratigraphic data by means of two boreholes, collecting of piezometric data and soil samples), and grain size analyses. Moreover, a Casagrande piezometer was set up in the superficial horizon to observe

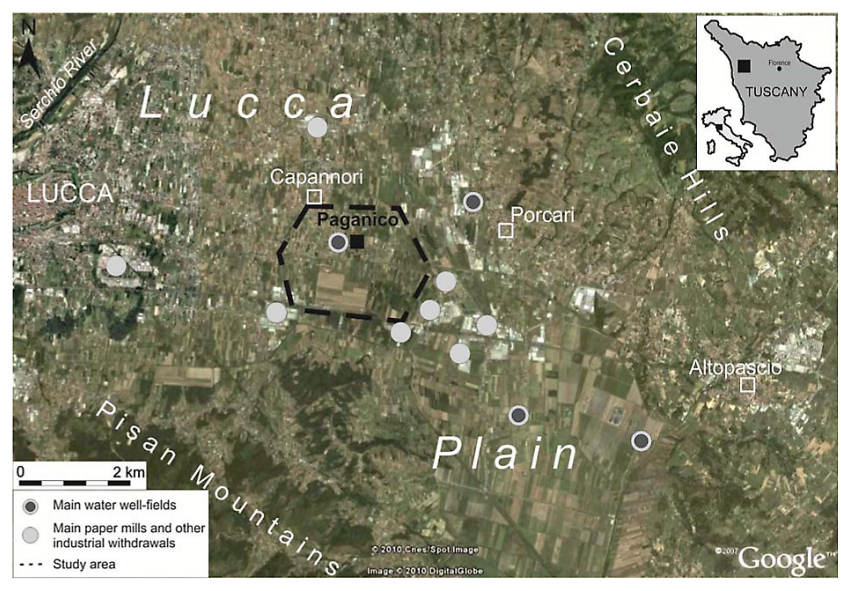

Fig. 1. Location map of the study area and main groundwater withdrawals (by Google).

and analyze the superficial water level and its relationship with the potentiometric surface of the confined aquifer. Unfortunately, the monitoring period was short, due to the destruction of the piezometer by ploughing.

\section{Geological setting}

In the Lucca Plain several geological, hydrogeological and paleogeographic studies were carried out (Nardi et al., 1987; Federici and Mazzanti, 1988; Puccinelli, 1991). The Lucca Plain bedrock, on which predominately Pleistocene fluviallacustrine sediments lie, is formed of different tectonic units (Tuscan Nappe, Pisan Mountains Metamorphic Core Complex, Internal and External Ligurian Units). Since the early Miocene, they have been involved in extensional processes, originating large depressions. In the Upper Villafranchian (according to Trevisan et al., 1971; Cantini et al., 2001; Sarti et al., 2001), the Lucca depression was covered by a vast lake (Bientina Lake), with deposition of clayey-silty-sandy sediments, interbedded by fluvial pebbles in the upper portion. After the lake-filling (Würm), the Lucca Plain began to take its actual form, as consequence of the erosional and depositional phases of the ancient Serchio River. The alluvial deposits, mainly gravels and pebbles in a sandy-silty matrix, have variable thickness and depth increasing towards the south. They are covered by more recent sandy-silty deposits, locally named "Bellettone". The latter are recognizable as far as hundreds of meters south of Paganico, partially surmounting the lacustrine deposits of the ancient Bientina Lake.

The lithostratigraphic sketch map of the study area, reconstructed by means of surface lithostratigraphic, geotechnical data and boreholes, is shown in Fig. 2, while Fig. 3 represents a lithostratigraphic section of the area most affected by sinkhole-like features. 
The underground of Paganico shows the following lithostratigraphic units (from top to bottom):

- sandy silt, 2-3 m thick, whose southern limit is included between the railway Lucca-Florence and the motorway Pisa-Florence (1 in Fig. 2); to the east it becomes clayey silt (2 in Fig. 2);

- clay, silty clay and clayey silt, $2-4 \mathrm{~m}$ thick in the Paganico area, increasing towards the south; the northern limit coincides with the shore of the ancient Bientina Lake (3 in Fig. 2);

- gravel and pebbles in sandy matrix (approximately 10 $m$ thick), with intercalation of sandy and clayey lens (Fig. 3).

\section{Hydrogeological characterization}

Owing to grain size features and geometrical structure of sediments, in the Paganico area two water levels are recognizable, separated by an impermeable horizon (lacustrine clayey silt). The first one is temporary, held in a perched aquifer (silty-sandy level) and directly fed by local rainfall; the second one is housed in the confined aquifer, generally under pressure, made of coarse alluvial deposits (gravel and pebbles). This is mainly fed by groundwater coming from the Serchio River (through paleochannels) and torrents circulating in permeable deposits, and from permeable rocks cropping out in the reliefs surrounding the area. Due to its high hydraulic conductivity and transmissivity ( $K=10^{-2} \div 10^{-4} \mathrm{~m} \mathrm{~s}^{-1}, T=10^{-2} \div 10^{-3} \mathrm{~m}^{2} \mathrm{~s}^{-1}$, respectively), this aquifer is highly exploited. Fig. 4 shows the general groundwater flow direction in the aquifer of the Lucca Plain, in which the NW-SE direction (according to the ancient course of the Serchio River) is recognizable.

The perched aquifer has a medium-low hydraulic conductivity ( $K=10^{-6} \div 10^{-7} \mathrm{~m} \mathrm{~s}^{-1}$, from literature date, on the basis of sediments grain size) and shows a temporary water table, being exclusively recharged by intense and prolonged rainfall. Due to its hydraulic conductivity value, this horizon is more properly an aquitard, but in order to simplify and considering its position and structure, it will be considered as a perched aquifer.

The piezometric level of the confined aquifer generally maintains a depth of about 1-3 m below the topographic surface near Paganico. The piezometric fluctuation quite rapidly follows the rainfall trend, characterized by an annual maximum between autumn and winter, and a secondary one in spring. During the dry seasons, the confined aquifer tends to depressurize, suffering from deficiency of water recharge and overexploitation.

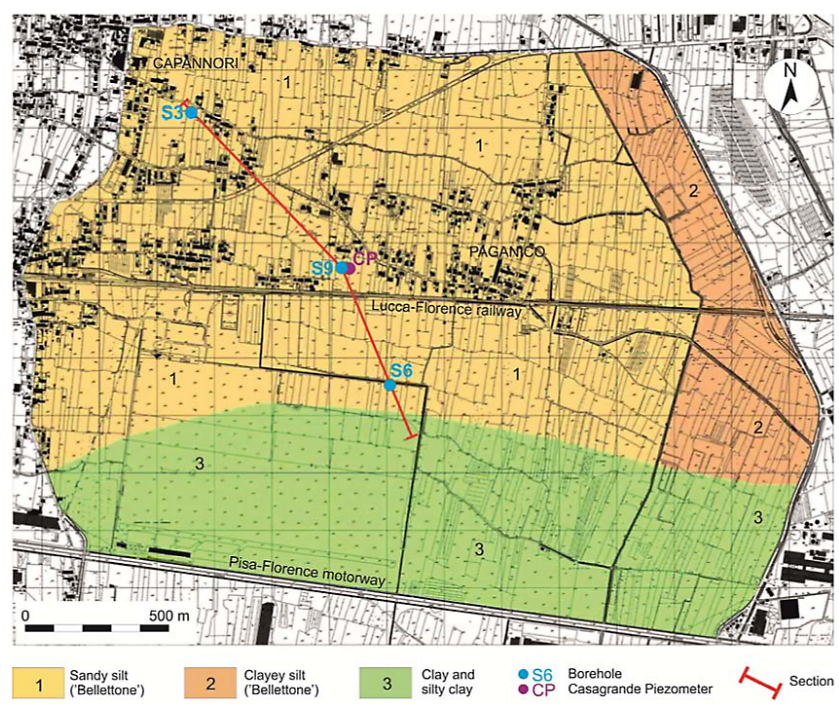

Fig. 2. Lithostratigraphic sketch map of the study area.

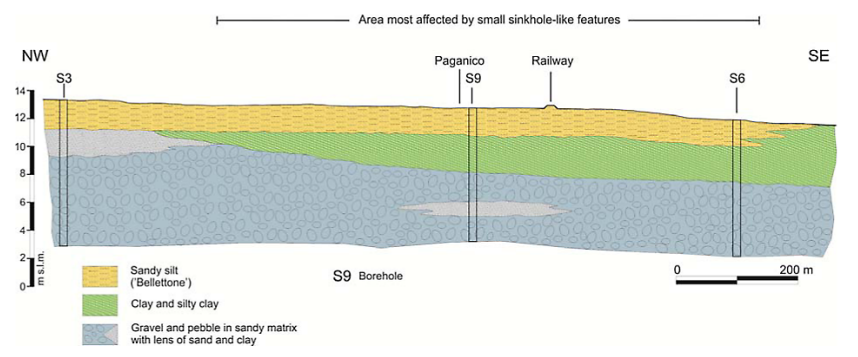

Fig. 3. Lithostratigraphic section of the area most affected by sinkhole-like features.

In order to understand the hydrodynamic regime of the perched aquifer and its relationship with the potentiometric surface of the confined aquifer, a Casagrande piezometer was set up in the superficial horizon. The monitoring period, from May 2008 to February 2009, was short because the piezometer was destroyed by ploughing activity. Nevertheless the first data collected may provide useful remarks. In Fig. 5 the water levels for both the perched and confined aquifers collected in different periods are shown. The piezometric level of the confined aquifer was measured in borehole S9 (see Fig. 1), about $10 \mathrm{~m}$ from the Casagrande piezometer.

The results of this short monitoring period show as the two piezometric surfaces are effectively separated. For example, on 7 July 2008 the piezometric level of the confined aquifer falls in the superficial horizon, but the superficial water table was not measured. It is possible that in some periods in which the clayey horizon allows the hydraulic communication, there is a hydraulic equilibrium. However, it probably lasts only a short time.

Magazzini (1998) studied the vertic properties of the soil using the Coefficient of Linear Extensibility (COLE) (USDA-NRCS, 1999), namely the ratio of the difference 


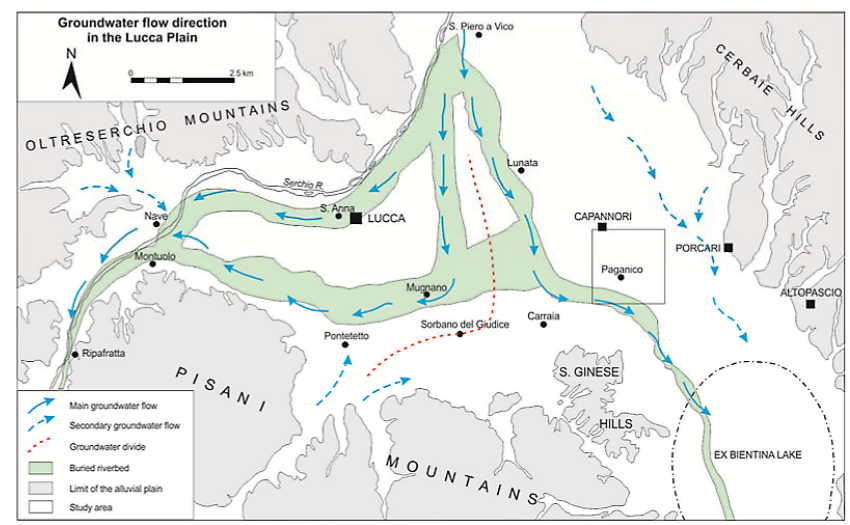

Fig. 4. Chief and secondary groundwater flow directions in the Lucca Plain (after Nardi et al., 1987, modified).

between the moist length and dry length of a clod to its dry length. According to the author, in the dry season the impermeable level between the perched and the confined aquifer below suffers cracking phenomena (Fig. 6), with a volume variation between 3 and $12 \mathrm{~cm}$ per meter in thickness. The author proved that cracking already begins with $30 \%$ in soil moisture, attributing a vertic behaviour. Vertic properties are defined as soil characteristics caused by the seasonal changes in volume, or shrinking and swelling. Cracks that open and close periodically, slickensides, wedge-shaped structural aggregates that are tilted at an angle from the horizontal, vertical infillings, and high linear extensibility values are good examples of properties associated with vertic soils (Gray and Nickelsen, 1989; USDA-NRCS, 1999). Thus, water can flow through the slickensides, eroding sediments (Jones, 1994; Meisina, 2006). Tang et al. (2008) observed that this type of sediment may crack depending on temperature, thickness of soil layer, times of wetting and drying cycles, and type of soil. These factors control the number of intersections and crack segments, and average crack length and width. Similar geological situations were also observed by Higgins and Schoner (1997) in California, where cracking reaches the gravel body as much as $10 \mathrm{~m}$ below the surface.

Magazzini (1998) moreover observed that desiccation can also produce fracturing in the sandy silt of "Bellettone", but with lower intensity: $1-3 \mathrm{~cm}$ per meter in thickness with $26 \%$ of moisture. These phenomena probably have a double effect: they increase the perched aquifer permeability (but there are not at present specific data resulting from on-site surveys) and assure hydraulic connection between aquitard and aquifer through the impermeable level.

\section{Small sinkhole-like features}

The study area has been subject to small sinkhole-like features for several decades, but only during the eighties did the collapses reach significant dimensions. The classic shape

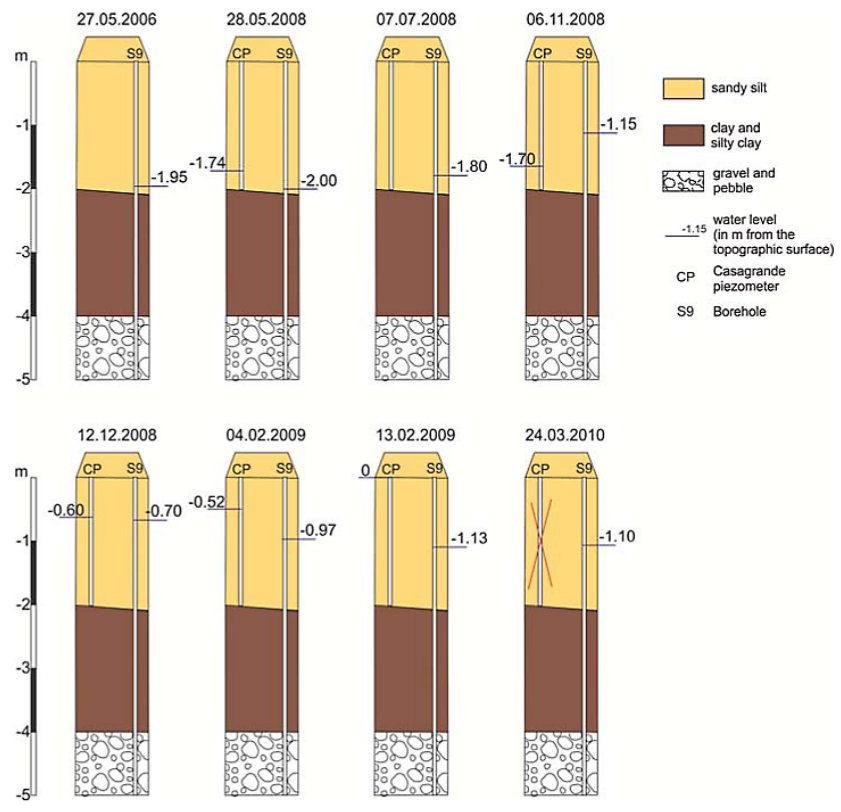

Fig. 5. Comparison between the piezometric levels observed in the perched aquifer and in the confined aquifer. On 24.03.2010 the Casagrande piezometer was destroyed.

is generally circular, with a diameter and depth of a few decimeters, but often small vertical conduits (diameter approximately within $10 \mathrm{~cm}$ ) have been observed. The main assessed sinkhole-like features and vertical conduits are more than 500 (number in continuous evolution) and have been subdivided on the basis of diameter and depth (Table 1 and Fig. 7).

Vertical conduits and sinkhole-like features (Fig. 8a) can be isolated and arranged at random, or be aligned along particular directions (usually $\mathrm{N}-\mathrm{S}$, more rarely $\mathrm{E}-\mathrm{W}$ ). Alternatively, they can be grouped as "swarms", often in parallel with the ditches direction. This different way of distribution was observed also by Verachtert et al. (2010).

From the bottom of the cavities, horizontal cylindrical tunnels, a few centimeters large, often depart (Fig. 8b). The sinkhole-like features can take different shapes such as cylindrical, conical, truncated-conical, and barrel-shape. (Fig. 9).

Approximately $60 \%$ of the Paganico sinkhole-like features are arranged in swarms, namely in groups of cavities substantially aligned (98\%), particularly according to $\mathrm{N}-\mathrm{S}$ direction. This orientation could be attributable to two causes: (a) the cavities are often near $\mathrm{N}-\mathrm{S}$-oriented ditches; and (b) ploughing furrows generally follow this direction and could represent potential water infiltration and circulation points. Only a few cases ( $2 \%$ ) showed a different direction of the swarms, for example $\mathrm{E}-\mathrm{W}$, again attributable to presence of ditches.

Sinkhole-like features and vertical conduits seem to develop in lithotypes characterized by prevailing silty-sandy fraction, while they tend to disappear in clayey-silty deposits. 
Table 1. Morphometric characteristics of the Paganico cavities and relative distribution.

\begin{tabular}{lllll}
\hline & $\begin{array}{l}\text { Diameter } \\
(\mathrm{m})\end{array}$ & $\begin{array}{l}\text { Depth } \\
(\mathrm{m})\end{array}$ & No. & $\begin{array}{l}\text { Distribution } \\
(\%)\end{array}$ \\
\hline Large sinkhole-like features & $0.7-2.8$ & $0.6-2.0$ & 10 & 2 \\
Medium sinkhole-like features & $0.3-0.7$ & $0.3-0.6$ & 76 & 15 \\
Small sinkhole-like features & $0.1-0.3$ & $0.1-0.6$ & 207 & 41 \\
Vertical conduits & $0.01-0.1$ & $0.3-0.5$ & 213 & 42 \\
\hline
\end{tabular}

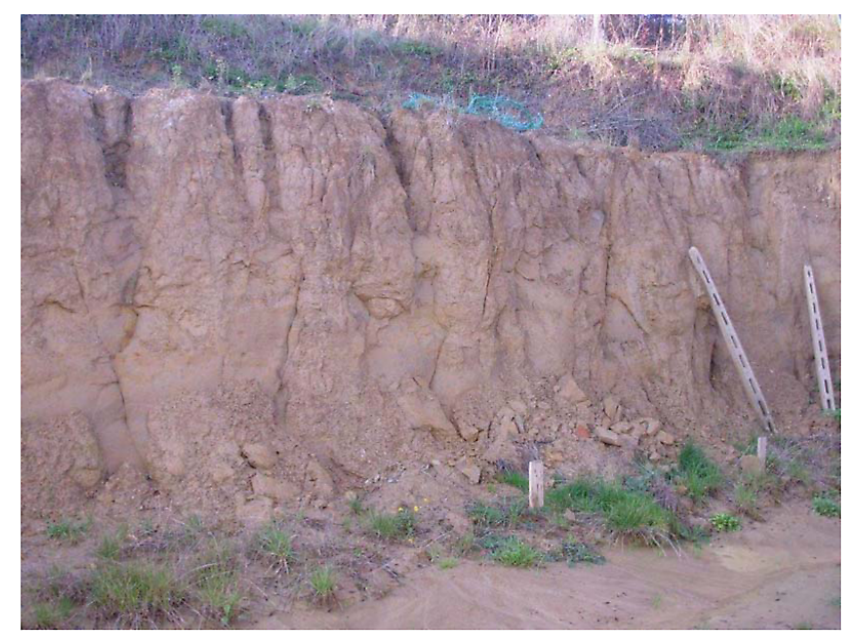

Fig. 6. An example of deep soil cracks affecting clay deposit near Paganico (the scarp is approximately $2 \mathrm{~m}$ high).

Even though the cavities especially involve the "Bellettone" deposit, they occur only when this particular stratigraphic sequence is present (from top to bottom, Fig. 3): sandy silt (recent alluvial deposits of Serchio River - "Bellettone"); silty clay (palustrine deposits); coarse alluvial deposits (paleochannels of Serchio River). The vertical conduits are mainly common south of Paganico (sandy silt), while the sinkholelike features prevail in the village (Fig. 7), where the sandy fraction increases.

Actually, some people attributed the origin of the tunnels and conduits to animal activity. However, most of the scientists who analyzed the phenomena tend to exclude this possibility. The tunnels dug by animals are usually chaotic, while those examined in the Paganico area often show symmetry. Moreover, no signs of animal transit were found, such as excrement, fur, etc.

In order to characterize the grain size distribution of the materials involved, 26 grain size analyses were carried out on samples collected in the upper and lower parts of the cavities and in areas not involved (at depth between 15 and $100 \mathrm{~cm}$ from the ground surface). The results (Fig. 10) confirm that sinkhole-like features and vertical conduits mainly involve the sandy silt and tend to disappear where the cohesive fraction increases, substantially stopping in proximity

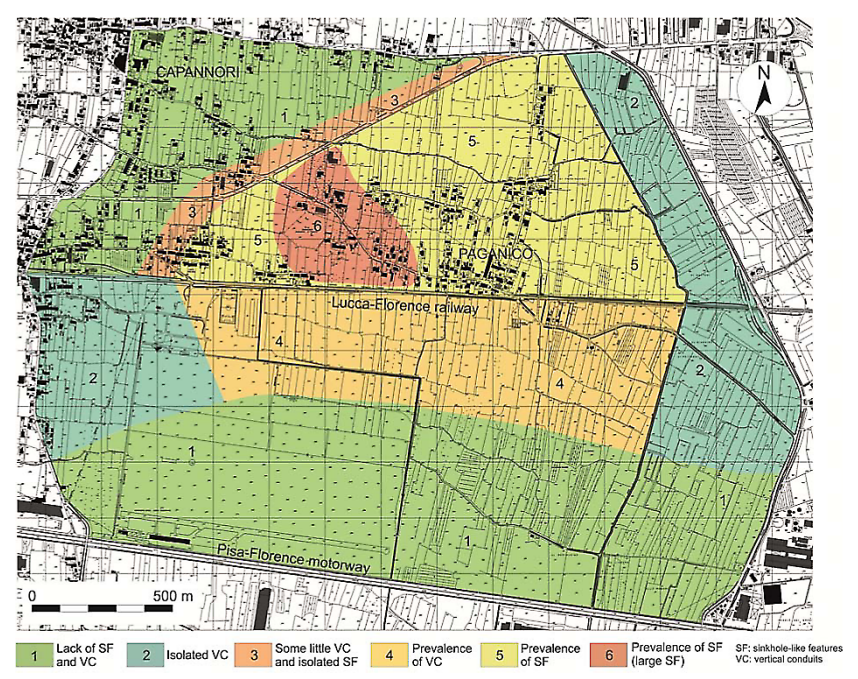

Fig. 7. Distribution of the sinkhole-like features in the Paganico area.
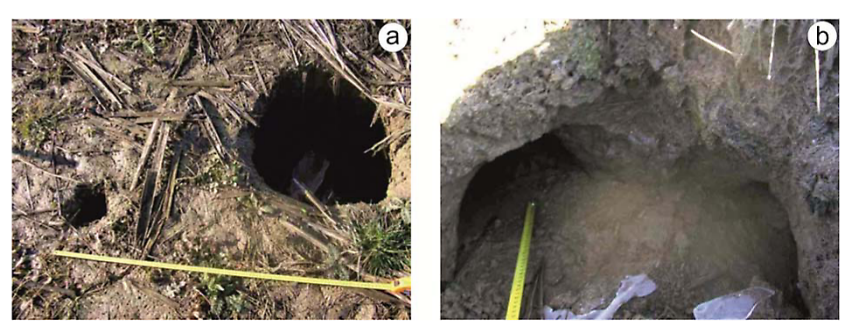

Fig. 8. (a) Vertical conduit (left) and sinkhole-like feature (right); (b) sub-horizontal tunnels departing from the bottom of the cavity.

of the contact between "Bellettone" and underlying palustrine sediments. In the zones without cavities, a considerable clayey fraction was observed.

The area most affected by sinkhole-like features is located near the Paganico water well field, where gullies sometimes developed (see Fig. 11e). They probably result from superficial horizontal tunnels, in which the erosional processes induced the vault thinning and collapse. As explained later, the larger dimension of these particular horizontal tunnels are probably associated with the greater erosional intensity near the well field, resulting from the higher hydraulic gradient between perched aquifer and confined aquifer. The formation 

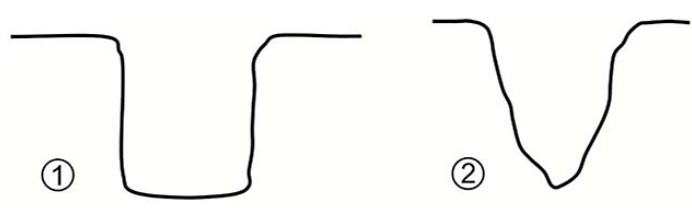

(3)

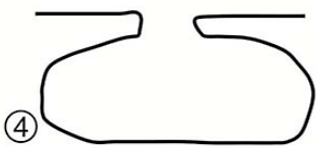

Fig. 9. Schematic sections of sinkhole-like features individuated in the Paganico area: (1) cylindrical, (2) conical, (3) truncated-conical, (4) barrel.

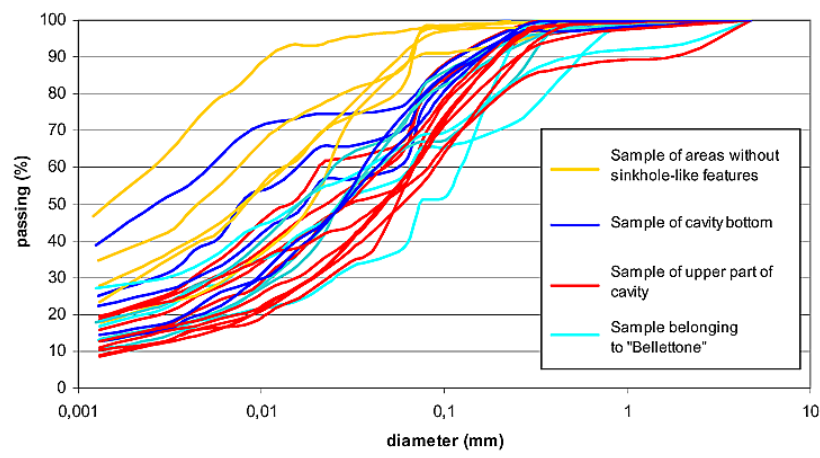

Fig. 10. Grain size distribution of the samples collected in the $\mathrm{Pa}-$ ganico area.

of gullies was observed also by Gutièrrez et al. (1997), while Verachtert et al. (2010) attribute their formation to the progressive collapse of several contiguous cavities.

It is interesting to notice the complete absence of sinkholelike features and vertical conduits north of the Pisa-Florence motorway (Fig. 7), where superficial clayey deposits, directly lying on the gravelly sediments, are present (eastern part in Fig. 3).

\section{Development mechanism}

As mentioned above, the small sinkhole-like features mainly develop from September/October to March, after long rainy periods or during heavy rainstorms (in the study area these are common in autumn). The development mechanism originating the cavities seems to follow two possible ways. The first one concerns the cavities far from ditches. In this case, the origin is probably associated with leakage between the perched and the confined aquifers, which should induce erosional phenomena through the desiccation cracks of the siltyclayey level. The second mechanism regards the sinkholelike features close to ditches, with the possible cause linked to the relation between the perched aquifer and the stream flow, as better explained in the following paragraphs.
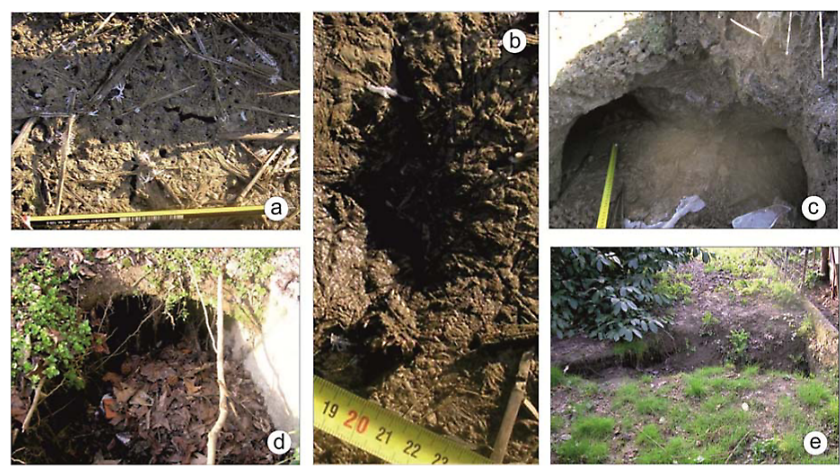

Fig. 11. Hypothesized evolutionary steps in sinkhole-like features formation: (a) little holes of water circulation along soil fractures; (b) partial hollow zone; (c) vault fall showing horizontal tunnels; (d) horizontal tunnels; (e) gully.

Analyzing the various shapes individuated on-site, both as precursory events and intermediate steps determining the formation of the cavities, it is possible to hypothesize the evolutionary process:

1. at the beginning of the rainy period the formation of micro-holes occurs along the vertical fractures produced by soil desiccation (Fig. 11a);

2. water seepage causes erosional phenomena, originating a little hollow at the surface (Fig. 11b);

3. the percolating water increases the erosional power, enlarging the micro-holes which become vertical conduits; moreover water tends to also circulate in the horizontal cracks, enlarging them due to hydraulic gradient and mechanical erosion. This phenomenon especially occurs along the contact between the sandy silt and the underlying clayey deposits, forming from centimetric to metric horizontal tunnels (Fig. 11c).

4. the intersection between horizontal tunnels and vertical conduits determines a soil structural fragility, and the collapse can occur, originating a small cavity (Fig. 11d);

5. in some cases, actually not frequent in the study area, collapse of superficial, long horizontal tunnels may result in the formation of gullies (Fig. 11e).

Some video still shots carried out by the Capannori Municipality seem to confirm the proposed developing model. The images show: (a) the presence of underground horizontal tunnels, containing debris deposits, probably attributable to previous falls (Fig. 12a); (b) the tunnels' shape, rounded at the vault and "v-shape" at the base, indicating runoff (Fig. 12a); (c) the presence of fractures and micro-holes on the cavities vault, proving their vertical continuity (Fig. 12b). Moreover, the images show the presence of abundant plant root systems 
(Fig. 12a). According to Sanglerat et al. (1984), vegetation is important in raising the erosional processes rate in swelling clay, favoring soil desiccation and cracking by suction. If cavities and horizontal tunnels are large, the roots become hanging and unable to absorb water. In time this induces the plant to wither and this may be considered as a premonitory sign of the presence of cavities in the ground.

The model proposed for Paganico presents analogies along with that suggested by Higgins and Schoner (1997), studying cavities in silty-sandy sediments in central California. In the same way, analyzing piping phenomena in several regions of Britain, Jones et al. (1997) ascribe the evolution from desiccation cracks to piping to water erosion. Soil subject to piping lies on clayey deposits, characterized by vertic properties and high shrinkage potential, likewise at Paganico.

\subsection{1st development mechanism - sinkholes-like features associated with water flow between perched aquifer and confined aquifer}

The sequence (Fig. 13) begins at the end of the dry season (step a), when the confined aquifer water level (CAWL; potentiometric surface) is low (not under pressure), while the perched aquifer water level (PAWL) is absent. In summer the superficial sediments desiccate. In autumn the rainy periods start, and the piezometric levels of aquifers grow (b). In relation to different hydraulic conductivity, the reaction time to rainfall of CAWL and PAWL is different (short for the confined aquifer, longer for the perched one). However, the PAWL, if present, is always higher than CAWL. As a consequence, hydraulic flow from the perched to the confined aquifer can occur through desiccation cracks, which are developed both in the intermediate clayey horizon and in the superficial silty-sandy sediments. The presence of water in the perched aquifer induces the soil volume to increase, closing the cracks (b). The same phenomenon was observed also by Van Breemen and Buurman (1998) and Tang et al. (2008) in other geographical environments. Contemporaneously, water involved in leakage exerts erosional actions along the fractures, opposing to the complete closing. Swelling also occurs in the clayey horizon, but probably after a certain delay, allowing erosional phenomena in the cracks during the first rainfall.

At the end of the rainy period (b1) the PAWL slowly reaches the maximum level, with a certain time lag as regards the CAWL (reached previously, b). During the b1 phase, leakage is intense, due to the greater difference of height between the piezometric levels. Thus cracks are further eroded, becoming little vertical conduits (b1, b2). Not all the desiccation cracks become vertical conduits, but only those in which the erosional power is greater. A predisposing factor may be, for instance, the presence of local ground depressions (associated with ploughing), which can intercept the runoff.

Moreover, it is possible (but actually it has not been proven) that cracks in the silty-sandy deposits do not join the
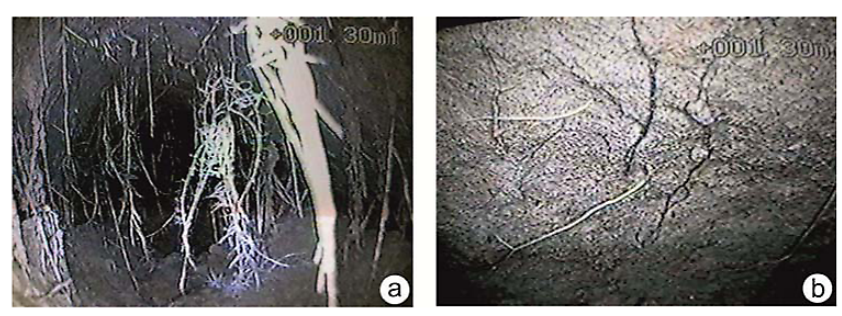

Fig. 12. Video still shot images (courtesy of Capannori Municipality). (A) internal part of horizontal tunnel; (B)detail of tunnel vault in which fractures, roots and micro-holes are recognizable.
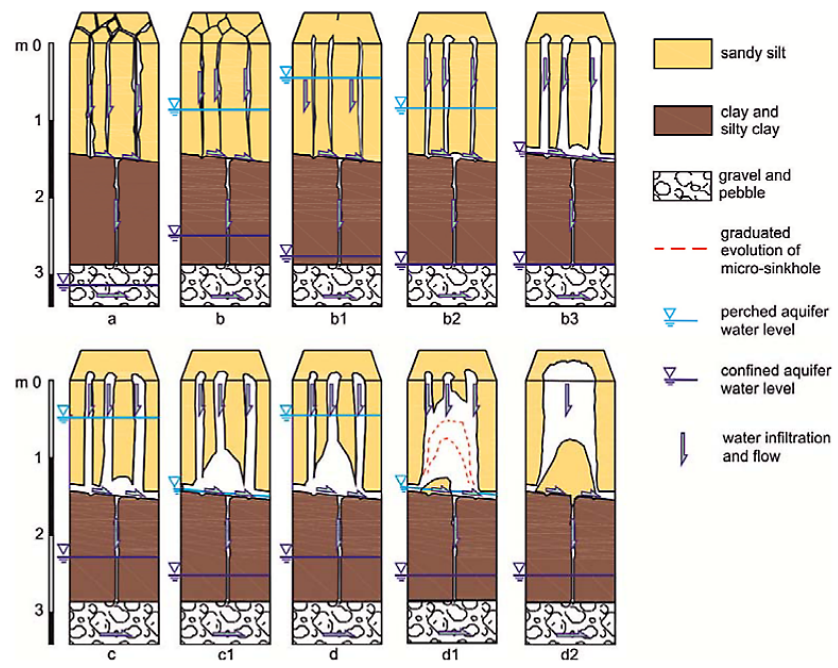

Fig. 13. Evolution sequence of sinkhole-like features produced by water flow between perched and confined aquifers: (a) dry period; (b) during and after rainy periods; (c) following rainy cycle; (d) collapse.

cracks in the clayey sediments. This, together with the slight gradient at the contact between sandy silt and clay, probably favor a sub-horizontal movement of water along the contact, due to the different hydraulic conductivity of the sediments. This erosional power of water flow should slowly produce horizontal tunnels (b2, b3). The intersection between vertical conduits and horizontal tunnels creates portions of structural weakness in which underground collapses may occur (b3). The evolution of horizontal tunnels and cavities may stop when the PAWL disappears and resumes in the following rainy period (c, c1, d). On-site surveys really allow the observation that, despite the return of rainy periods, tunnels preserve their features due to sediments' plasticity.

The erosional process involving the superficial sandy silt may be quickened by leakage when the piezometric levels allow it. In time, sequences of rainy periods imply the progressive increase of the cavities size till the collapse (d1, d2). The material eroded is then probably dispersed by water flow. Therefore, the erosional processes are activated by leakage phenomena. This is not a simple particle capture 
under pumping effects (Panno et al., 1994; Leake, 2004) or subsidence induced by compacting (Rosepiler and Reilinger, 1977; Melidoro et al., 1996; Galloway et al., 1999; Del Prete et al., 2010).

In order to individuate the area most exposed to leakage, a schematic and simplified map of the hydraulic gradients between PAWL and CAWL was produced (Fig. 14) making two assumptions: (1) since continuous measures of PAWL fluctuation are not available, it was considered at the ground surface; (2) the CAWL, stressed by intense pumping, was considered at the minimum level, namely below the gravel aquifer "roof" (testified by several piezometric surveys in dry seasons). This approach individuates the study area into four classes of sinkhole-like features susceptibility:

- class I $(i=0)$ : area lacking in cavities and conduits, where lacustrine clayey deposits are present;

- class II $(0.1<i<0.6)$ : area with sporadic cavities and conduits, where clayey silt is present;

- class III $(0.6<i<1.0)$ : area with large number (70\% of total) of cavities (diameter and depth $<1 \mathrm{~m}$ ) and conduits (diameter $<4 \mathrm{~cm}$ ), where sandy silt is present;

- class IV $(1.0<i<1.9)$ : area located close to the Paganico groundwater well field, characterized by the remaining $20 \%$ of phenomena, including the larger cavities (diameter from 0.7 to $2.8 \mathrm{~m}$, depth from 0.6 to $2.0 \mathrm{~m}$ ), vertical conduits (diameter from 4 to $8 \mathrm{~cm}$ ), and gullies, where sandy silt is present.

Comparing the hydraulic gradient map (Fig. 14) with the sinkhole-like features distribution (Fig. 7), an increase in number and dimension of phenomena is recognizable where the hydraulic gradient is higher. Sinkhole-like features developing far from ditches preferentially originate where pumping is stronger, determining a higher drawdown in the confined aquifer, as close to the Paganico well field.

\subsection{2nd development mechanism - swarms of sinkhole-like features associated with water flow between perched aquifer and ditches}

Several sinkhole-like features (swarms) may be aligned along the same direction (Fig. 15a) and connected by horizontal tunnels (Fig. 15b). Approximately $60 \%$ of the identified cavities belong to $\mathrm{N}-\mathrm{S}$-oriented swarms. This should be in relation to several reasons: (1) the contact between sandy silt ("Bellettone") and silty clay (lacustrine deposits) slopes to the south; (2) the ploughing furrows, which direct the surface runoff and increase infiltration rate and erosion, are $\mathrm{N}-$ $\mathrm{S}$-oriented; (3) ditches and canals are mainly $\mathrm{N}-\mathrm{S}$-oriented.

Figure 16 synthesizes the mechanism of water flow between ditches and water table. In summer, the silty-sandy sediments tend to dry and crack (Fig. 16a). Autumnal rainfall

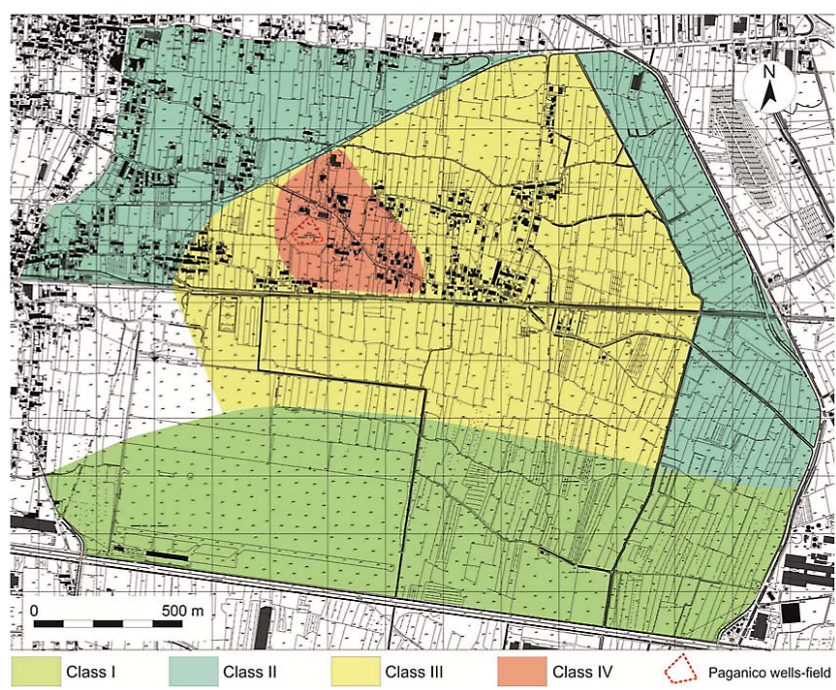

Fig. 14. Hydraulic gradient $(i)$ map; class I $(i=0)$ : lack of sinkholelike features and vertical conduits; class II $(0.1<i<0.6)$ : sporadic phenomena; class III $(0.6<i<1)$ : $70 \%$ of identified phenomena (sinkhole-like features: diameter and depth $<1 \mathrm{~m}$; vertical conduits: diameter $<4 \mathrm{~cm})$; class IV $(1<i<1.9)$ : $20 \%$ of identified phenomena (sinkhole-like features: diameter 0.7-2,8 m, depth 0.6-2 m; vertical conduits diameter: $4-8 \mathrm{~cm}$ ).

rapidly recharges the ditches, which drain the fields, while the PAWL has a longer response time (Fig. 15b). This determines water flow between ditch and sides, with alternate direction basing on the water level variation (Fig. 16bc). The phenomenon continues until reaching a substantial equilibrium (Fig. 16d). These flows likely produce erosional phenomena in particular weakness zones of soil, originating vertical conduits (along the vertical cracks) and horizontal tunnels (along the horizontal plain, where flow is more lasting). In some cases, the communication between cavities and canals was proved by a flexible rule.

Actually, this model should be more complex, because in some situations and in consideration of the hydrostratigraphic conditions, the two developing mechanisms could coexist.

\section{Conclusions}

The study carried out in the Paganico area allowed for the individuation of some important factors in the formation of sinkhole-like features. If the triggering cause is basically certain (rainfall intense and prolonged, able to originate a water table in the perched aquifer and stream flow in ditches), some uncertainties remain regarding the predisposing factors. One of the most important is surely the lithostratigraphic-hydrogeological structure. This consists of superficial silty-sandy levels ("Bellettone", mediumlow hydraulic conductivity), lying over almost impermeable 

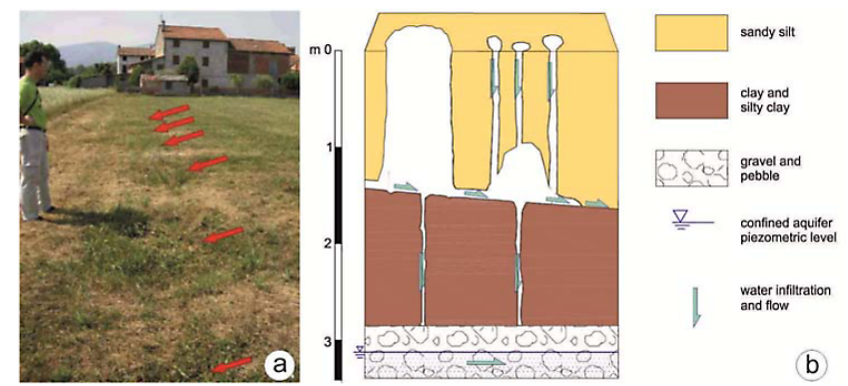

Fig. 15. (a) Swarm of filled sinkhole-like features N-S-oriented (the cavities are recognizable by more green grass, due to greater moisture). (b) Sketch of sinkhole-like features connected by subhorizontal or lightly sloping tunnels.

clayey-silty sediments. Below, a very permeable gravel level is present, hosting a considerable groundwater circulation. This aquifer is particularly stressed by pumping wells ( $\mathrm{Pa}-$ ganico well field, wells of several paper factories, and numerous domestic wells), determining a strong drawdown. On the other hand, the superficial silty-sandy sediments (perched aquifer) may occasionally house a temporary water table, after intense and prolonged rainfall.

It has been hypothesized that at the end of the dry season, both the superficial silty-sandy horizon and the clayey-silt below may suffer desiccation phenomena, originating vertical and horizontal cracks. During rainfall following the dry season, such cracks favor water circulation, saturation and formation of a water level in the perched aquifer, which is involved in vertical leakage. This induces erosional phenomena in the superficial silty-sandy horizon, formation of vertical conduits and horizontal tunnels and collapse of the weaker areas.

The sinkhole-like features seem more frequent near ditches limiting fields, where the erosional processes are probably associated with water flow between the water table and the ditches during intense rainfall.

The lithostratigraphic-hydrogeologic structure of Paganico seems therefore to represent the most important factor in developing sinkhole-like features. In fact, in spite of the presence of paper factories and water wells, there are not cavities either to the north (lacking the intermediate clayey-silty horizon) or to the south (lacking the superficial silty-sandy sediments). Both situations imply the presence of only one aquifer and consequently there is no leakage. Pumping can induce cavities only if the cone of depression develops in the typical lithostratigraphic situations just described, as in the Paganico wellfield area. This confirms the importance of the strong drawdown induced by pumping in the gravelly confined aquifer. In the past, when exploitation was moderate, the water pressure in the aquifer prevented this phenomenon, while several resurgences were present in the Paganico area.

Relationships between pumping and sinkhole-like features were also emphasized by Davidson (2012), even if in that

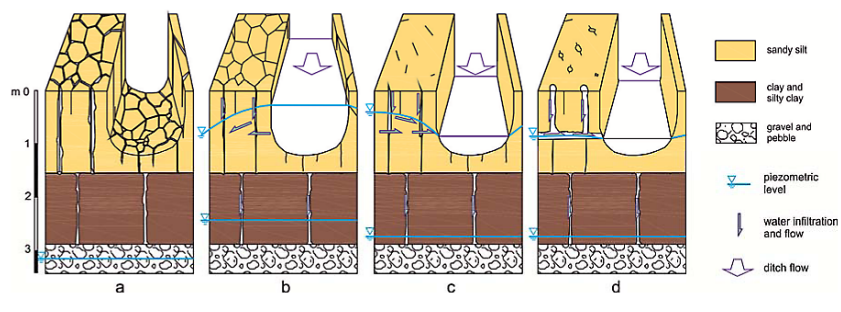

Fig. 16. Supposed developing sequence for sinkhole-like features caused by flows between water table and ditches ((a), dry period; (b), beginning heavy rainfall; (c), just after rainfall; (d), approximately 10-15 days after the rainfall period).

case the small cavities were formed as the result of the slow decomposition of tree stumps in an area with high water table, followed by rapid decomposition and vertical holes formed when pumping and water table drawdown resulted in aeration (G. R. Davidson, personal communication, 2013).

To better comprehend the origin of the small sinkhole-like features at Paganico, several studies are still needed. One of the most important actions should be to perform a continuous monitoring of the water level in the perched aquifer and its relationship with both the confined aquifer and ditches by means of Casagrande piezometers, in the attempt to quantify the rainfall amount able to generate this water level. Further studies should be directed towards the analysis of the soil desiccation phenomena and the complete geotechnical characterization of involved materials. In particular, data on index properties, plasticity, compressibility and degree of saturation certainly would help in understanding the swelling/shrinking occurrence. Specific hydraulic conductivity and tracer tests can be useful in determining the permeability features of the soils.

Finally, on the basis of the results obtained in this research, in order to reduce or rather to eliminate the sinkholelike features hazard in the Paganico area, the hydraulic pressure of the confined aquifer should be increased, keeping the piezometric level above the aquifer "roof". This basically consists in limiting and controlling the groundwater exploitation associated with the Paganico well fields and/or using artificial water recharge techniques. Alternatively, the well fields should be moved to more favorable areas from a hydro-stratigraphic standpoint. Moreover, the Paganico village should be linked to the aqueduct network to eliminate or reduce domestic well activity.

Alternative water supplying should also be individuated for paper factories (e.g., water recycling, external derivation), a problem that has been discussed for many years but has remained unsolved so far. 
Acknowledgements. The authors are grateful to the Geotechnical Laboratory of the Civil Engineering Department (University of Pisa) and in particular to Mr. Stefano Giusti, for the grain size analyses carried out under the supervision of Profs. Diego Lo Presti and Nunziante Squeglia. The authors wish to thanks also the Editor Mario Parise and the anonymous reviewers, whose suggestions significantly improve the manuscript.

Edited by: M. Parise

Reviewed by: two anonymous referees

\section{References}

Bates, R. L. and Jackson, J. A.: Glossary of geology. American Geological Institute, 3rd Edn., Alexandria, VA, 788 pp., 1987.

Bryan, R. B. and Jones, J. A. A.: The significance of soil piping processes: inventory and prospect, Geomorphology, 20, 209-218, 1997.

Cantini, P., Cavallini, R., Testa, G., and Zanchetta, G.: The PlioPleistocene evolution of extensional tectonics in northern Tuscany, as constrained by new gravimetric data from the Montecarlo basin (lower Arno Valley, Italy), Tectonophysics, 330, 2543, 2001.

Canuti, P., Casagli, N., Farina, P., Ferretti, A., Marks, F., and Menduni, G.: Land subsidence in the Arno river basin studied through SAR Interferometry, Proc. 7th Int. Symp. on Land Subsidence, Shanghai, China, 23-28 October 2005, 1, 407-416, 2005.

Davidson, G. R.: Micro-sinkhole development from groundwater pumping in a non-karst system, Geol. Soc. Am. Abstracts with Programs, 44, p. 11, 2012.

Del Prete, S., Iovine, G., Parise, M., and Santo, A.: Origin and distribution of different types of sinkholes in the plain areas of Southern Italy, Geodinam. Ac., 23, 113-127, 2010.

Federici, P. R. and Mazzanti, R.: L'evoluzione della paleogeografia e della rete idrografica del Valdarno inferiore, Boll. Soc. Geogr. It., Ser. XI, 5, 573-615, 1988.

Fife, D. L.: Engineering geologic significance of giant desiccation polygons, Lucerne Valley playa, San Bernardino County, California. Geol. Soc. Am. SP, 252, 1-28, 1977.

Galloway, D., Jones, D. R., and Ingebritsen, S. E.: Land subsidence in the United States, U.S.G.S., Circular 1182, http://pubs.usgs. gov/circ/circ1182/ (last access: January 2013), 177 pp., 1999.

Galve, J. P., Gutiérrez, F., Remondo, J., Bonachea, J., Lucha, P., and Cendrero, A.: Evaluating and comparing methods of sinkhole susceptibility mapping in the Ebro Valley evaporite karst (NE Spain), Geomorphology, 111, 160-172, 2009.

Garcìa-Ruiz, J. M., Lasanta-Martinez, T., Ortigosa-Izquierdo, L., and Arnànez-Valdillo, J.: Pipes in cultivated soils of La Rioja: origin and evolution, Z. Geomorphol., 58, 93-100, 1986.

Garcìa-Ruiz, J. M., Lasanta, T., and Alberto, F.: Soil erosion by piping in irrigated fields, Geomorphology, 20, 269-278, 1997.

Ghelardoni, R., Giannini, E., and Nardi, R.: Ricostruzione paleogeografica dei bacini neogenici e quaternari nella bassa Vale dell'Arno sulla base dei sondaggi e dei rilievi sismici, Mem. Soc. Geol. It., 7, 91-106, 1968.

Gray, M. B. and Nickelsen, R. P.: Pedogenetic slickensides, indicators of strain and deformation processes in redbed sequences of the Appalachian foreland, Geology, 17, 72-75, 1989.
Gutiérrez, M., Sancho, C., Benito, G., Sirvent, J., and Desir, G.: Quantitative study of piping processes in badland areas of the Ebro Basin, NE Spain, Geomorphology, 20, 237-253, 1997.

Higgins, C. G. and Schoner, C.: Sinkholes formed by piping into buried channels, Geomorphology, 20, 307-312, 1997.

Jones, J. A. A.: Soil piping and its hydrogeomorphic function, $\mathrm{Cu}-$ aternario y Geomorfologìa, 8, 77-102, 1994.

Jones, J. A. A., Richardson, J. M., and Jacob, H. J.: Factors controlling the distribution of piping in Britain: a reconnaissance, Geomorphology, 20, 289-306, 1997.

Leake, S. A.: Land subsidence from ground-water pumping. USGS, http://www.savethesantacruzaquifer.info/Land\%20Subsidence. htm (last access: January 2008), 2004.

Magazzini, P.: Indagini sull'idrologia sotterranea e sulla crepacciabilità di un suolo mediante utilizzo di traccianti e misure di estensibilità lineare (COLE) in località Paganico (Comune di Capannori), Capannori Municipal Administration, unpublished technical report, 16 pp., 1998.

Marr, J. C.: Sinkholes in irrigated fields, Calif. Agr., 9, 6-7, 1955.

Meisina, C.: Characterisation of weathered clayey soils responsible for shallow landslides, Nat. Hazards Earth Syst. Sci., 6, 825-838, doi:10.5194/nhess-6-825-2006, 2006.

Melidoro, A., Melidoro, N. L., and Simeone, V.: Primi casi di subsidenza in Puglia prodotta da emungimento d'acqua da pozzi, Mem. Soc. Geol. It., 51, 49-12, 1996.

Nardi, R., Nolledi, G., and Rossi, F.: Geologia ed idrogeologia della pianura di Lucca, Geogr. Fis. Din. Quat., 10, 132-160, 1987.

Neal, J. T., Langer, A. M., and Kerr, P. F. Giant desiccation polygons of Great Basins playas, Geol. Soc. Am. Sci., 252, 77-110, 1968.

Panno, S. V., Wiebel, C. P., Heigold, P. C., and Reed, P. C.: Formation of regolith-collapse sinkholes in southern Illinois: interpretation and identification of associates buried cavities, Environ. Geol., 23, 214-220, 1994.

Parise, M. and Florea, L. J.: I sinkholes nella letteratura scientifica internazionale: una breve rassegna, con particolare riferimento agli Stati Uniti d'America, Mem. Descr. Carta. Geol. d'It., 85, 427-450, 2008.

Puccinelli, A.: Nuovi aspetti dell'evoluzione paleogeografia e tettonica al Plio-Quaternario della piana di Lucca (Toscana), Geogr. Fis. Din. Quat., 14, 171-177, 1991.

Rosepiler, M. and Reilinger, R.: Land subsidence due to water withdrawal in the vicinity of Pecos, Texas. Eng. Geol., 11, 295-304, 1977.

Sanglerat, G., Olivari, G., and Cambou, B.: Practical problems in soil mechanics and foundation engineering, Elsevier, 2, 283 pp., 1984.

Sarti, G., Zanchetta, G., Mazza, P., and Grassi, R.: Sedimentological and palaeontological features of an ancient alluvial plain in the Lucca Basin (Central Italy), Eclogae Geol. Helv., 94, 107-117, 2001.

Sbrilli, L.: Fenomeni diffusi di sinkholes nella Pianura del Fiume Cornia soggetta a subsidenza, Proc. Congr. "Stato dell' Arte sullo studio dei fenomeni di sinkholes e ruolo delle amministrazioni statali e locali nel governo del territorio", ARPAT, Rome, 20-21 May 2004, 639-649, 2004.

Tang, C., Shi, B., Liu, C., Zhao, L., and Wang, B.: Influencing factors of geometrical structure of surface shrinkage cracks in clayey soils, Eng. Geol., 101, 204-217, 2008. 
Trevisan, L., Brandi, G. P., Dallan, L., Nardi, R., Raggi, G., Rau, A., Squarci, P., Taffi, L., and Tongiorgi, M.: Note illustrative della Carta Geologica d'Italia alla scala 1:100.000 - Foglio n. 105 (Lucca), Min. Ind., Comm., Artig., Roma, 1971.

USDA-NRCS (United States Department of Agricolture-Natural Resources Conservation Service): Soil taxonomy, a basic system of soil classification for making and interpreting soil survey, Agricultural Handbook, 436, 871 pp., 1999.

Van Breemen, N. and Buurman, P.: Soil formation, Earth and Environmental book, part C, chapter 10 "Formation of vertisols", 233-244, 1998.
Verachtert, E., Van Den Eeckhaut, M., Poesen, J., and Deckers, J.: Factors controlling the spatial distribution of soil piping erosion on loess-derived soil: a case from central Belgium, Geomorphology, 118, 339-348, 2010.

Waltham, T. and Fookes, P. G.: Engineering classification of karst with respect to the role and influence of caves, Q. J. Eng. Geol. Hydroge., 36, 101-118, 2003.

Waltham, T., Bell, F., and Culshaw, M.: Sinkholes and subsidence: karst and cavernous rocks in engineering and construction, Springer, 382 pp., 2005.

Warn, F.: Sinkhole development in the Imperial Valley, in: Engineering Geology in Southern California, edited by: Lung, R. and Proctor, R., Association of Engineering Geologists, Los Angeles Section, Spec. Publ., 144-145, 1966. 